\title{
A Review on Political Factors Influencing Public Support for Urban Environmental Policy
}

\begin{abstract}
Environmental quality is important to urban residents' physical, social and psychological well-being. Governments have been formulating and implementing policies to mitigate environmental deterioration in cities. To effectively enacting policies and achieving policy goals, gaining sufficient public support is a prerequisite, otherwise, the policy would be in ruins and the government may suffer from setbacks in other policies. Therefore, to understand what contributes to public support is a crucial task for policymakers. Though current literature on socio-demographic and attitudinal/psychological factors provides fruitful accounts for policy support, a comprehensive examination of political determinants has yet to be established. In response to this, this review paper explores political factors that influence level of policy support based on existing literature. An integrated framework is proposed for explaining policy support for urban environmental policy. This paper also discusses the possible directions of future research.
\end{abstract}

Keywords: policy support; public acceptance; willingness to pay; urban environment; urban policy; politics

\section{Introduction}

\subsection{Background}

Nations around the world encounter growing urban environmental problems ranging from water pollution, air pollution, excessive waste, loss of biological diversity, climate change, to name just a few examples (Hardoy et al., 2013; Satterthwaite, 2003; Van Kamp et al., 2003). To address the severity of environmental problems and improve the livability of the environment, governments have set up environmental institutions and designed various types of policy measures and regulations. For instance, early in 1970 the U.S. government established Environmental Protection Agency (EPA) which intends to control pollution and protect the environment via laws and regulations (Kamieniecki \& Kraft, 2013). Apart from institutions set up, different types of policy frameworks and measures have been proposed in many countries and across continents. For example, Europe 2020, a strategy which includes targets of greenhouse gas emissions reduction, and promotion of renewable energy usage and efficient use of energy (López-Mosquera et al., 2015); or measures such as mandatory source separation of waste in Nagoya, Japan (Ohnuma et al., 2005). Although cases of successfully implementing environmental policies like plastic bags levy can be found (Convery et al., 2007), not every policy initiatives and measures are welcomed by the public. Some of these policies were rejected because of a lack of policy support (Kim et al., 2013). For example, both French carbon tax in 2010 and road pricing in Edinburgh in 2005 encountered opposition from the public and failed to be implemented at the end (Kallbekken \& Sælen, 2011). Therefore, gaining sufficient public support would be essential to effectively implementing measures to deal with environmental problems in cities.

\subsection{Defining policy support}

Support in a board sense is defined as an individual's underlying attitude or behaviour towards an object, it can be expressed in overt (e.g., action or advocacy) and covert (e.g., 
evaluation) behaviours (Easton, 1975). Policy support refers to how an individual orients himself to government's policies through his attitudes or behaviours. Citizens' support for environmental policy can be presented by different means, for example, willingness to pay higher taxes for environmental action, approval of environmental regulations, or endorsement of allocating more resources on environmental protection (Stern, 2000; Wan et al., 2015), which has indirect effects on the environment. Public policy, as one type of formal institutions, can change behaviours of individuals (North, 1990). Accepting or supporting an environmental policy implies that citizens are more willing to engage in behaviours shaped or guided by the policy, e.g., paying taxes, saving energy, therefore, public support would indirectly extend the effects on the environment (Stern, 2000). Kollmuss and Agyeman (2002) put forward a similar view by arguing that policy support is an indirect pro-environmental behaviour.

Recruiting support from citizens plays a critical role in both governance and policy-goal achievement. It is a way of which existing political authority seeks approval from the governed and secures it from potential overthrow by the public. If a policy is well equipped with public support, a government is able to institute the policy in a rather smooth way; and gaining support from the public also facilitates the authority to achieve policy objectives (Rauwald \& Moore, 2002). Support for environmental policy contributes to minimization of harmful effects on and protection of the environment. Therefore, to understand underlying factors of policy support is a key condition to reach effectual environmental policies and foster pro-environmental behaviours among the public.

\subsection{Prior studies on policy support for environmental policies}

Over the last two decades, a profusion of studies has been conducted to examine the correlations between level of policy support and socio-demographic factors such as age, gender, education, and income (for a comprehensive review on socio-demographic factors, see Dietz et al., 1998 and Jones \& Dunlap, 1992). Age and education are suggested to be the most consistent predictors among socio-demographic factors (Dietz et al., 1998). Young people are proved to be more supportive for spending on environmental protection than older generations (Dunlap et al., 2000; Jones \& Dunlap, 1992). Education can raise individuals' environmental awareness (Daniels et al., 2013; Torgler \& García-Valiñas, 2007). An educated individual is expected possessing a positive environmental attitude and being more supportive of increased environmental spending (Dietz et al., 1998; Dunlap et al., 2000; Israel \& Levinson, 2004). Nonetheless, a few studies found mixed results for age and education variables, for example, Grønhøj and Thøgersen (2009) found that the elderly engage in more pro-environmental activities than young people; Uyeki and Holland (2000) reported that education level is not a significant factor of pro-environmental behaviours. Compared to age and education, gender is a less stable factor of policy support that the results vary across studies. In some studies women are generally proved to be more concern with environment than men and appear to be more supportive for pro-environmental actions (Hunter et al., 2004; Zelezny et al., 2000), and more willing to pay higher taxes for environmental protection (Jones \& Dunlap, 1992; Stern et al., 1993). Interestingly however, Blocker and Eckberg (1997) suggested that women, compared with men, are less actively engaging in public pro-environmental behaviours. Income is also an inconsistent predictor of environmental concern compared to other socio-demographic factors. On the one hand, it is assumed that affluent people can afford more pro-environmental actions than their poor counterparts. Studies of environmental concern on global scale reveal that people in countries with higher GDP would devote more efforts on environmental protection than those in 
developing countries (Franzen, 2003; Inglehart, 1995). On the other hand, some scholars suggested that people in wealthier countries do not necessarily perform more proenvironmental behaviours as those in poor countries do (McCright \& Dunlap, 2013; Mostafa, 2012; Uyeki \& Holland, 2000). Though above generalization on environmental behaviours does not appear across variables, these studies provide a necessary basis in understanding the relationships between socio-demographic factors and policy support.

A second line of research has been eagerly investigating policy support in connection with attitudinal/psychological matters. Of which, the Value-Belief-Norm theory (VBN) constructed by Stern et al. (1999) provides a comprehensive account for exploring individuals' support and acceptance of environmental policies. The VBN theory links value theory, norm-activation theory, and the New Environmental Paradigm in a causal chain sequence (Stern, 2000; Stern et al., 1999). According to the theory, values of a person (biospheric, altruistic, and non-egoistic) would directly activate one's belief in ecological worldview, then belief in adverse consequences of environment, and finally belief in perceived ability to reduce threat to the environment. The sequence of induced-beliefs leads up to personal norms such as a sense of obligation to take pro-environmental actions. The causal chain engenders four types of behaviours, namely, activism, non-activist public sphere behaviours (e.g., supporting environmental policies, theme of this paper), private sphere behaviours, and behaviours in organizations. In order to test the predictive power of VBN theory for three types of non-activist environmentalism, that is, environmental citizenship, private-sphere behaviour, and policy support (willingness to sacrifice), Stern et al. (1999) compared the VBN with six other theories such as postmaterialist values. Empirical results suggested that the VBN theory had a significant predictive power for non-activist behaviours, among which policy support obtains the highest score. The result revealed that the VBN theory does have a significant explanatory power in policy support (Stern, 2000; Stern et al., 1999). The theory is adopted in a number of studies for testing the acceptability of environmental policies (Steg et al., 2005) and its explanatory power is generally recognized (Steg et al., 2012).

\subsection{Bridging the gap: the call for examining political matters}

The summarized literature on socio-demographic and psychological aspects only contributes a piece of puzzle to explaining people's support for environmental policy. As Kollmuss and Agyeman (2002) suggested, scholars should expand the realm to other fields for exploration of unattended but crucial factors for enrichment of discussion. Matti (2015) also argued that in order to grasp a full condition for the model of policy support, characteristics related to policy instruments itself such as fairness should be counted in for investigation. Only a few numbers of study echoed to the suggestions. For example, Ebreo et al. (1996) and Harring and Jagers (2013) investigated the impacts of procedural fairness and political trust, respectively, on policy support for urban environmental policies. Other focused on specific political factors, e.g., political affiliation (Dupont \& Bateman, 2012), public participation (Daley, 2013; Halvorsen, 2003), and policy preferences (Daniels et al., 2013). However, the fragmented investigations failed to grasp a full picture of the issue; therefore, this review aims to answer the following research question: what are the political determinants of level of policy support. The contribution of this study is to identify and discuss the political factors of policy support and convert them into the axes of our proposed conceptual model for analysis of urban environmental policies. 
Conceptually, this paper contributes to the theoretical understanding of political environment of environmental policies. Practically, this yields a threefold benefit in regard to governance. First, governments can gauge a more thorough understanding of potential policy supporters and improve environmental policy formulation process resulting in recruiting more supporters for its policies. Second, a policy with strong public support can enhance policy legitimacy that would facilitate public compliance with government's rules and regulations (Levi \& Sacks, 2009; Wallner, 2008). Third this review establishes a referential value for other policies' formulation and implementation process.

This review will first identify political factors that explain level of policy support from available literature. A conceptual framework based on these factors would be proposed for analyzing public support for environmental policy. The framework provides a new dimension for future research studies of policy support. Moreover, the newly identified political factors, together with socio-demographic and psychological factors form a three-dimension conceptual block which can shed light on the complexities of policy support.

\section{Methods}

\subsection{Search parameters}

A systematic review was adopted to identify factors influencing level of policy for urban environmental policies, with special emphasis on politically-induced factors. The methodology is a replicable, systematic, and transparent review process with minimum bias and it can provide researchers with a comprehensive and critical body of literature (Bilotta et al., 2014; Tranfield et al., 2003). The research question of the present study involves research areas related to environmental policy, public policy, and social sciences. For this reason, Scopus was chosen as the targeted database because it is a multidisciplinary database which enables researchers to search the scope of literature from a wide range of subjects and journals.

The concept "policy support" in the field of environmental studies first appeared in studies by Stern et al. (1999) and Stern (2000), thereby a search string was developed by selecting keywords from these two studies to perform literature retrieval. Table 1 presents the word variants of selected keywords used in this study. The search was conducted under the combined field "article title, abstract, keywords" in Scopus. The searching timespan was restricted to the years 1991 - 2016. The document type was set as "Article or Review" and subject area was limited to "Social Sciences \& Humanities".

Table 1 Search string

\begin{tabular}{ll}
\hline Keywords & Word variants \\
\hline Policy support & $\begin{array}{l}\text { "policy support" or "public support" or "public acceptance" or "policy acceptance" or } \\
\text { (willingness and (pay or sacrifice)) }\end{array}$ \\
Environment & "environmental" or "environment" \\
Factor & "factor" or "influence" or "determinant" \\
Policy & "policy" or "politics" or "political" or "government" \\
\hline
\end{tabular}




\subsection{Selection criteria and information categorization}

The search was conducted in June 2016 and the search protocol returned an initial sample of 282 articles. Since the document type was set as articles or review, documents related to book reviews, conference papers, dissertations, and editorials were automatically excluded in the retrieved literature. The first selection process was performed based on screening title, abstract, and keywords of the articles. Non-English written papers were excluded. We have also weeded out irrelevant papers which only mention search keywords in title, abstract, and keywords section but research objective is not dealing exclusively with policy support and environmental policy. The first filter left a pool of 106 eligible articles for further analysis.

In the second stage, we have read the full text of 106 articles and classified them into the following four categories by applying corresponding criteria listed below. As previously mentioned, a majority of current literature investigates level of policy support in relation to demographic and psychological factors; and a few number of studies touched upon political factors. This review paper suggests that existing literature of policy support can be divided into following categories, and categorization criteria were developed by drawing reference to studies conducted by Gifford (2014), Matti (2010, 2015), Schuitema and Bergstad (2012), Steg and Gifford (2008), and Steg and Vlek (2009).

a) Demographic category (Gifford, 2014):

Level of policy support is determined by demographic factors such as age, gender, education, income, etc.

b) Psychological category (Steg \& Gifford, 2008; Steg \& Vlek, 2009):

Determinants of policy support investigated are related to individuals' mental processes like cognitions and motivations.

c) Political category (Matti, 2010, 2015; Schuitema \& Bergstad, 2012):

Factors influencing level of policy support are concerned with political context and practices.

The second stage revealed that 27 out of 106 articles focus on relationship between politically-driven-factors and policy support for environmental policy. The remaining are papers (79 articles) examining environmental policy support from demographic and/or psychological perspectives. In other words, there is around $25 \%$ of articles retrieved from database Scopus specifically examine political factors. Distribution of different categories of these articles was depicted in Figure 1.

Since the review question focuses on politically-induced factors, only 27 articles would be included for review purpose. Relevant backward and forward citations were checked for these 27 articles. 10 additional articles were found by following above filtering processes (ag), adding up the number of articles related to political factors to 37 in total. Owning to relative few numbers of relevant articles found, we have replicated the search processes in other databases (i.e., EBSCOhost Academic Search Premier, JSTOR, ProQuest, SpringerLink, and Wiley Online Library) by applying and repeating the same searching string and selection processes. An additional 51 articles and book chapters were found. The final sample for review consisted of 88 documents (Appendix 1). 


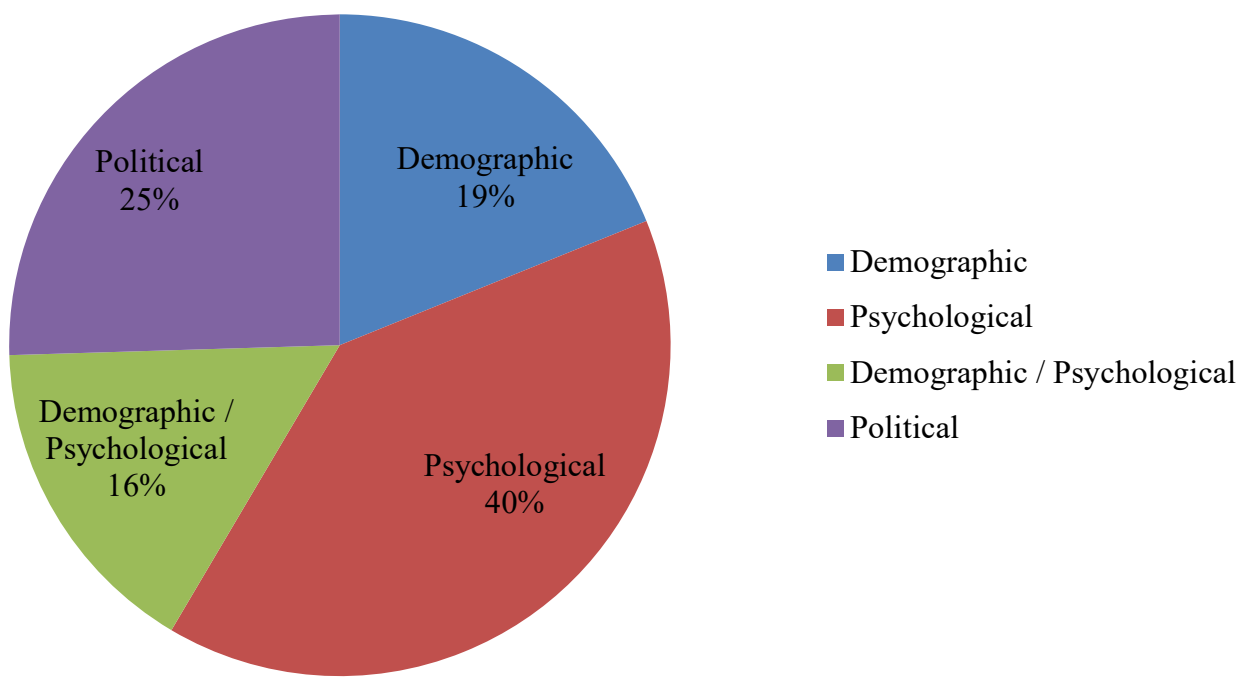

Figure 1 Overview of selected papers retrieved from Scopus (106 articles)

\subsection{Extracting findings and interpretation}

This review paper aims to identify and collate political drivers from the sampled articles, and to develop a new conceputal model which is based on these factors for policy support analysis. A full-text review was conducted to first identify all political factors discussed in sample articles. Next, we documented and characterized the identified factors by their definition synthezied from the articles and it turned out that these factors can be grouped as follows: political trust, procedural and distributive fairness, political affiliation, participatory process, and policy preference.

Specifically, if the factor in the articles concerns about people's confidence or degree or trust in government in relation to policy support for environmental policy, it would be grouped as political trust. For articles investigate whether the policy formulation process and outcome would be transparent, fair, and objective, the concerned factor was labelled as procedural and distributive fairness. Political affiliation is about respondents' ideology, political inclination, or political stance on the matter of environmental policy. Regarding participatory process, articles of this factor are most likely to be focused on public engagement in policy formulation and implementation process and the subsequent effects on public support for environmental policy. Finally, if articles touch upon public's preferences over policy or issue of environmental policy agenda-setting, and their relationship with level of policy support, then we defined this political factor as policy preference. A structured summary and discussion of main findings (Bilotta et al., 2014) of each political factor will be reported in remaining sections. The narrative review allows us to reach a more critical and in-depth discussion and evaluation of political determinants in influencing the level of policy support. 


\section{Review of political factors influencing policy support}

\subsection{Political trust}

Political trust is generally defined as people's belief or confidence in the government that it will produce outcomes which are consistent with their expectations (Easton, 1975; Harring \& Jagers, 2013; Hetherington, 2006; Kollmann \& Reichl, 2015; Konisky et al., 2008; Miller, 1974; Zannakis et al., 2015), and it is recognized as a crucial factor that influences individuals' level of support for environmental policies. A trustworthy government can engender the public's willingness to comply with laws, to support government initiatives, and to follow political leadership without needing to be coerced (Warren, 1999). In contrast, a distrusted government would result in lack of trust in anything that the government proposes to the public (Johnson \& Scicchitano, 2000). Kollmann and Reichl (2015) suggested that insufficient trust in governments and politicians is the root cause of people's reluctance to support environmental policy instruments.

Studies conducted by Harring and Jagers (2013) and Kollmann and Reichl (2015) found that political trust is a significant factor in determining one's willingness of supporting environmental taxes. According to the studies, there are two reasons lay behind individuals' willingness to support for environmental taxes. One is that people's confidence in the government, the belief that the government will deal the environmental taxes revenues in a righteous, effective, and proper way, and would not spend the revenues for purpose other than environmental protection (Harring \& Jagers, 2013; Kollmann \& Reichl, 2015). Another concern is people's perception that the government is capable in combating environmental problems (Harring \& Jagers, 2013). These two concerns form the basis of political trust which together effect policy support of a policy. In addition to economic sacrifices (Harring, 2013; Kyselá, 2015), political trust is proved to be significant in predicting other supportive behaviours such as acceptance of environmental rules (Zannakis et al., 2015) and giving approval to additional government actions for environmental protection (Konisky et al., 2008; $\mathrm{Xu} \& \mathrm{Li}, 2016)$. The positive impacts of trust on policy support are also proved in the field such as air quality or reclaimed water policies (Hartley, 2006; Lubell et al., 2006; Ormerod \& Scott, 2013). In sum, these studies prove that political trust has a positive impact on degree of policy support. Trust-building work is therefore important to be recognized by policymakers for formulating and implementing for urban environmental policies (Jenkins-Smith \& Kunreuther, 2001; Johnson \& Scicchitano, 2000).

Political trust can be given to specific political objects or institutions, for example, the government as a whole, politicians, political groups, legislature, judiciary system, or even bureaucratic agencies (Citrin \& Muste, 1999; Levi \& Stoker, 2000). Acknowledged by the operational distinctions, several studies operationalize political trust for different political referents in their studies. For example, Johnson and Scicchitano (2000) found that American respondents' level of trust towards university scientists who involved in environmental decision-making is higher than local public authorities. Zannakis et al. (2015) conducted a similar investigation on public acceptance of environmental rules and found that political trust towards specific enforcement authorities is a stronger predictor of policy support but not trust in institutions in general. These results provide evidence for the argument proposed by Levi and Stoker (2000) that, the public's behaviours are presumably driven by their trust toward particular authorities, and trust in particular institutions does not necessarily imply an equal level of trust in government as a whole.

Page 7 of 24 


\subsection{Procedural fairness \& distributive fairness}

Individuals are the ultimate receivers of most environmental policies. People are binding to pay for their pollution (e.g., solid waste charging fee) or environmental taxes or to change their behaviours (e.g., mandatory recycling) for better environment (Stern et al., 1999). Thus, individuals given any environmental policy context bear a certain degree of burden and responsibility, either in terms of financial cost or non-financial sacrifice. In light of this, people pay a considerable attention to the ways which policy decisions are made and the outcomes that affect them. Individuals' attitudes and support towards a policy is in part shaped by perceived justice (Kals \& Russell, 2001) which consists of two aspects of fairness, i.e., procedural fairness and distributive fairness (Clayton, 1998, 2000; Reese \& Jacob, 2015). Lind and Tyler (1988) defined the term procedural fairness as the fairness of procedures used to determine outcomes. According to Tyler and Bies (1990), procedural fairness includes consistency with rule of law, respectful treatment to individuals, sufficient representation of citizens, and effective channel for citizens to raise their voices. Distributive fairness is regarded as that given a policy framework, responsibility and cost-benefits shared by every social member should be distributed in accordance to fair principles and no groups or individuals are placed in a disadvantaged position (Folger, 1996; Kim et al., 2013; MacCoun, 2005).

The concepts are discussed in a burgeoning of studies which examined environmental policy acceptability. Rasinski et al. (1994) proposed fairness as one of the motivations for explaining support for environmental spending. Their study concluded that fairness is a guiding principle governing people whether to support government spending on the environment compared with other social spending. Recent studies investigated the relationships by paying attention to a particular urban environmental policy. For example, Kim et al. (2013) found that an individual's perception of fairness is the most important direct determinant on public acceptability of road pricing and environmental taxation policies in New Jersey, US and London, UK. Furthermore, Chung et al. (2011) proposed a model for testing prices fairness and tourists' willingness to pay for natural conservation in America. The study's findings supported that fair user fees policy is positively related to willingness to pay. A number of studies focused on urban transportation policy and road pricing. These studies showed that fairness positively relates to individuals' support for these policies (Börjesson et al., 2016; Börjesson et al., 2012; Börjesson et al., 2015; Kim et al., 2013). The notion of fairness also applies to understanding supportive behaviours for waste management policies. Ohnuma et al. (2005) conducted a study in Nagoya, Japan and found that citizens' approval of a new recycling policy is positively influenced by both procedural and distributive fairness. Similarly, Rahardyan et al. (2004) proved that fairness of locating of a waste management facility is strongly correlated with citizens' support. Lima (2006) examined the impact of procedural justice and distributive justice on acceptance of waste incineration facilities in two Portugal cities, negative perception of justice is found to be correlated to unfavourable attitudes towards the incinerator. The two notions have been included in the studies about community acceptance of treated urban stormwater (Mankad et al., 2015) and water allocation decision (Syme et al., 1999).

Though literature proves fairness is a significant predictor of policy support, some studies treat fairness as a psychological factor rather than a political determinant of policy support (Kim et al., 2013; Rasinski et al., 1994). However, it should be acknowledged that decisionmaking procedures are politically determined. It is because the government reserves the 
rights of providing citizens with a just, transparent, and inclusive policy decision-making process; in other words, whether there are fair procedures totally depending on the government's intention of creating such decision-making environment. Therefore, procedures and its outcomes should be regarded as politically-induced factors instead of a psychologically-induced result. In sum, both procedural and distributive fairness act as a motivator of policy support. The fairer the procedures and outcomes, the greater public support the policy would gain. Failure to observe the fairness principles may result in losing support from citizens or even disobedience of policies.

\subsection{Political affiliation}

Political affiliation is proved to be a powerful predictor of environmental policy attitudes (Dunlap et al., 2001; Konisky et al., 2008; McCright, Dunlap, et al., 2014; McCright, Xiao, et al., 2014). Many studies considered political ideology in a liberal-conservative continuum where liberals are placed on the left-side and the right-side represents conservatives (Dupont \& Bateman, 2012; Konisky et al., 2008; McCright, Xiao, et al., 2014; Uyeki \& Holland, 2000). By referring to a brief definition of political spectrum by Liu et al. (2014), liberals are individuals who believe in the role government in solving social problems for that the government should play an active role in minimizing socioeconomic divergence by regulating business behaviours and protecting collective well-being of the society. On the contrary, conservatives favour individual liberty for which any intervention from the government is discouraged because they believe in the role of market which can bring the society back to an equilibrium status. Liberals and conservatives are therefore on the opposite end of political spectrum.

The cleavage in political view reflects in environmental issues. Uyeki and Holland (2000) proved that conservatives are less environmental concern and tend not to accept environmental policies. This is because most environmental policies will increase greater costs, either for the government or individuals (e.g., increasing government spending on environment protection, taxing individuals to reduce adverse effects on environmental that caused by their behaviours), and emphases on regulations for controlling behaviours of both private sectors and individuals. All these measures would lead to an infringement of freedom and trade-off of economic development, which contradict to political views of conservatives. Dunlap et al. (2001) further reaffirmed the argument empirically in a study in the United States that liberals have greater adherence to environmental policies than conservatives. A large amount of literature revealed that self-reported liberal people or Democrats in America consistently show greater support to environmental protection programmes (Carman, 1998; Davis \& Fisk, 2014; Dietz et al., 2007; Elliott et al., 1997; Konisky et al., 2008; McCright, Xiao, et al., 2014; Stoutenborough et al., 2014). Results from other countries, e.g., United Kingdom (Clements, 2012; Dupont \& Bateman, 2012), Switzerland (Tobler et al., 2012), Spain (Torgler \& García-Valiñas, 2007), and in cross-national studies (Haller \& Hadler, 2008; Neumayer, 2004) are more or less the same.

To measure political affiliation and its impacts on environmental attitudes, current scholars generally employ different national-wide survey dataset as primary data source for analysis. For instance, General Social Survey conducted by US National Opinion Research Centre is adopted for analysis (Elliott et al., 1997; Uyeki \& Holland, 2000), or other annual environmental polls conducted by research companies (Dunlap et al., 2001; McCright, Xiao, et al., 2014). To tap individuals' political views, two measurements, self-labeled political ideology and party orientation, are generally used. Respondents are usually required to 
indicate their position on the political ideological continuum by rating a Likert scale (Konisky et al., 2008); while party orientation is commonly coded as several term descriptions from a range of strong literals to strong conservatives. To conclude, studies discussed above found that political affiliation is a consistent and significant predictor of environmental policy support, and it is not only applicable to the U.S. context but also in other countries around the world.

\subsection{Participatory process}

Traditional participatory mechanisms in environmental context include public notices, public hearings, written comments, suggestions boxes, etc. These strategies, however, can only involve a small number of the general public and lack sufficient communication with the stakeholders (Beierle \& Konisky, 2001; Daley, 2013). It is common that the government already has preliminary decisions and solutions of the concerned problems (Innes \& Booher, 2004). The traditional participatory mode is thus labeled as a government initiated approach which the general public plays a passive role throughout the policy decision-making process (Johnson, 2010). A number of scholars shared a similar view and suggested that a bottom-up approach which involves a broad participants, deliberative processes and collaborative public participation should be adopted (Beierle \& Konisky, 2001; Garnett \& Cooper, 2014; Petts, 2001). The practice is a set of process which involves a broad stakeholders (e.g., individuals, NGOs, interests groups, and organizations) to actively participate in all stages of decisionmaking process, and to influence and share control over policy decisions that may affect them (Havel, 1996; Reed, 2008). The process not only serves as a platform of aggregating public opinion towards policy, it can also increase transparency of decision-making process which improves citizens' satisfaction in and legitimacy of policy decisions; which, in return, recruits more supporters for a policy (Hartley \& Wood, 2005; Rietig, 2016; Roomratanapun, 2001; Shepherd \& Bowler, 1997).

Previous studies on public participation in environmental policymaking recognized that effective participatory process can gain decision legitimacy and increase public support for the policy (Chess \& Purcell, 1999; Cuppen et al., 2012; Luyet et al., 2012; Petts, 2001; Reed, 2008; Renn, 2006). Four major principles for successful public participation can be summarized. First, the general public should be provided with opportunities for early participation in policy decision-making process because early participation allows general public to influence planning process, contribute to high quality decisions and thus foster more responsive policies that meet citizens' needs (Chess \& Purcell, 1999; Garnett \& Cooper, 2014; Luyet et al., 2012; Reed, 2008; Roberts, 2004). Second, a broad range of public participation enables the authority to capture a wide range of perspectives of concerned issues. It allows public authorities to incorporate knowledge from different stakeholders and reach holistic management approaches for environmental problems (Bloomfield et al., 2001; Junker et al., 2007; Kapoor, 2001); in return, it can increase public acceptance of decisions (Junker et al., 2007). Third, deliberative process is regarded to be a vehicle to garner more support that should provide stakeholders with sufficient information on the environmental problems, and chances to critically judge and discuss presented values, evidence, and proposals (Garnett \& Cooper, 2014; Hartley \& Wood, 2005; OECD, 2009; Petts, 2000, 2001; Reed, 2008; Renn, 2006). Last, degree of influence plays a positive role in shaping policy support that public's value and vision should play a role in the policy decision process (Cuppen et al., 2012; Gariepy, 1991; Halvorsen, 2003; Shepherd \& Bowler, 1997; Webler et al., 1995). Being responsive to public input offers citizens a sense that the government is committed to 
participatory process by considering and weighting their opinions during decision-making process (Beierle \& Konisky, 2000; Garnett \& Cooper, 2014; Webler et al., 2001).

Findings from the prior studies provide fertile ground for understanding constituents of public participation. By taking these aspects into account can yield better management of public participation, which is recognized to be crucial for contributing to policy success (Cuppen et al., 2012; Luyet et al., 2012). The above summarized principles provide public authorities in managing the participatory process and may also serve as the basis for construct measurements.

\subsection{Policy preference}

Policy preference is an indicator for policy support. It refers to the public's interest in or desire for a particular kind of policy than other policies else (Page \& Shapiro, 2010; Wlezien, 1995). Due to the scarce of resources, environmental policies compete against other policies for resources (León \& Araña, 2016a, 2016b). For example, there is a possibility of reduction of welfare spending if the government allocated more financial resources on environmental protection; or the society may put a cost on economic development if environmental protection is being emphasized (Elliott et al., 1995; Inglehart, 1995). Similarly, competing for resources can be found between different environmental issues or problems. Limited resources create a preference gap between the general public and policymakers. Policymakers and the public may have diversified weighting over specific policies with regard to their concerned issues, resulting in differences between enacted policy and public agenda (Daniels et al., 2013; Page \& Shapiro, 1993; Podhora, 2015). It is suggested that keeping close with public preferences allows policymakers to formulate a policy which can gain greater support from the public (Dunlap, 2002; Guber, 2003; Milon \& Scrogin, 2006).

Public preference over a policy is subject to change in response to particular events. For example, Leiserowitz et al. (2006) pointed out that the Three Mile Island nuclear accident directed an attention shift of policies. Timing for initiating policy is an important aspect which warrants understanding of the public's policy preferences. The notion is similar to what Kingdon (1995) proposed, the opening of policy window (i.e., an opportunity to introduce a new policy) depends on public attention to a particular kind of issue and putting the issue onto policy agenda. In regard to problem tackling, The World Bank (1993) suggested that selection of appropriate policies for tackling problems matters in determining individuals' willingness to pay for expenditure of water planning policies. To sum up, right timing of initiating a policy offers opportunities to policymakers to mobilize support for the public. The appropriate enforcement tools can foster public support for the policy (Wan et al., 2015).

The public's policy preferences can be measured by public opinion survey either in a crosssection or longitudinal study. Preferences is often tapped by most important problem (MIP) questions such as "which policy area do you consider should be given priority". Another common approach for eliciting individuals' evaluation of environmental conservation and sense of environmental priorities is Contingent Valuation Method (CVM). In a study by Blaine and Smith (2006), respondents were presented with a series of environmental issues and they were required to rate the issues on a Likert scale. Identified preference from public opinion is regarded to be a reference of agenda setting and policy decision (Daniels et al., 2013; Lester, 1995; Major \& Atwood, 2004). There are surprisingly rare of empirical studies and discussions on the mechanism of policy preferences that influencing policy support. Still, 
from literature discussed above the potential value of policy preferences in explaining public support is made clear. The more a policy matches with preferences of large majorities (i.e., policy decisions are congruence with expectation of the general public), the more likely that the people would show support for the policy.

\subsection{Synthesis of political factors: a new conceptual model for policy support analysis}

As mentioned in preceding sections, the field has been filled with a large volume of studies of policy support in relation to socio-demographic and attitudinal/psychological variables. Evidence from literature suggested that the context in which the policy is formulated and implemented should not be excluded from examination of level of policy support. This paper addresses the gap by constructing a political conceptual model for the advancement of explaining the phenomenon of policy support.

Figure 2 illustrates the logic of the conceptual model that explains the ways of which political factors affect the level of policy support. As depicted in the diagram, a perspective of contributed-relationship is emphasized in the model. Five identified politically-induced factors, namely, political trust, procedural and distributive fairness, political affiliation, participatory process, and policy preferences, independently contribute to the dependent variable, that is, the level of policy support. A high level of political trust among people engenders the willingness to support a policy or comply with regulations. A policy which is formulated by fair principles and with fair outcomes is more likely to be accepted by the public. Sufficient public participation also increases the pool of policy support as the participatory process allows people to make their voice heard and reach a more favourable decision as a result. People also welcome policies which are initiated at a right timing and with appropriate instruments, and favour policies that are consistent with their political stance. In brief, every political factor independently shapes public's perceptions towards a policy. Positive interactive results between people and the political environmental and a good quality of policy would generate a greater amount of policy support. 


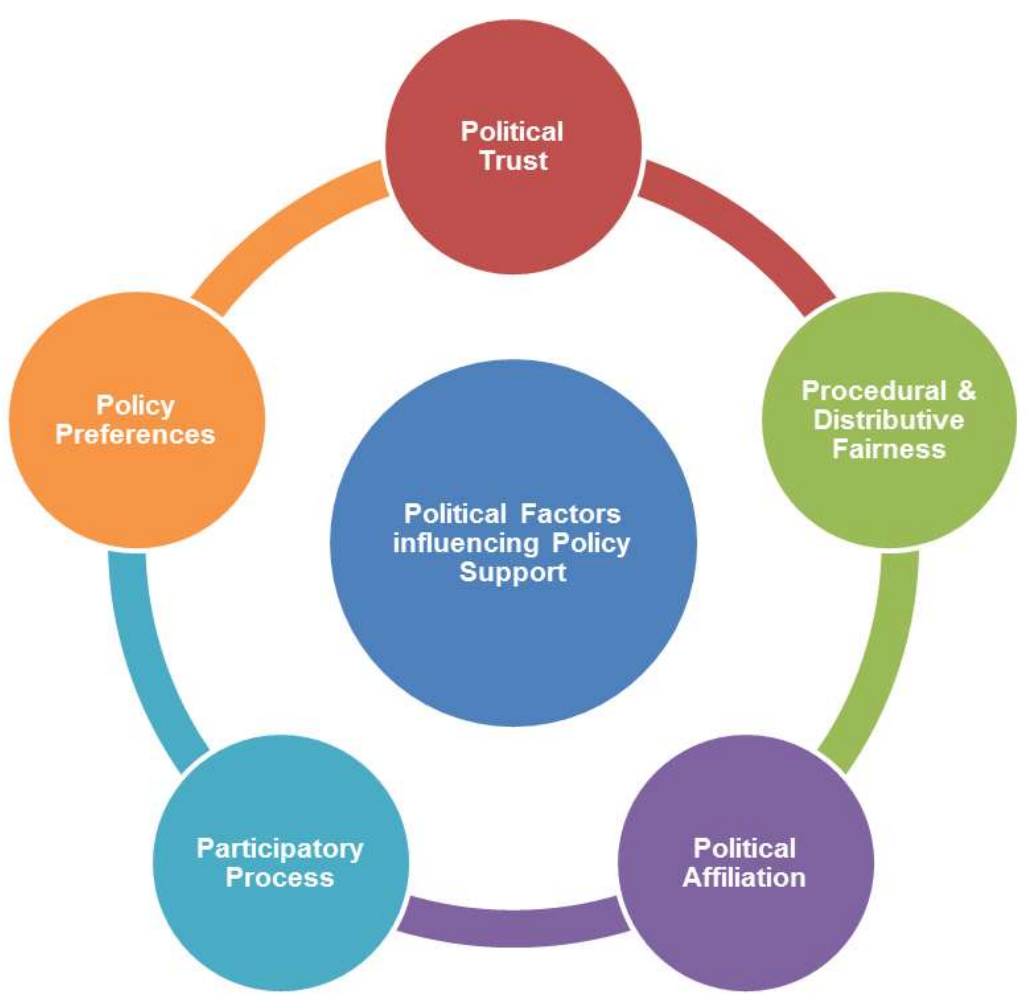

Figure 2 The political conceptual model explaining support for urban environmental policy

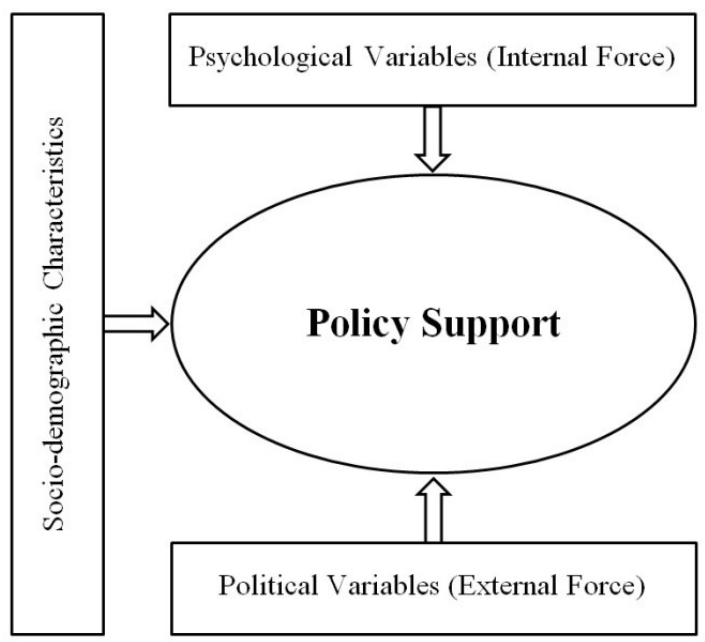

Figure 3 The conceptual framework - public support for urban environmental policy

The newly-constructed political model, together with socio-demographic and psychological blocks, forms a conceptual framework which comprehensively facilitates the examination of policy support (Figure 3). We treat individuals' socio-demographic characteristics such as social class and education level as static variables since they are predetermined and little change could be found over time. Still, the variables form the basis of determining the level 
of policy support of individuals. As for psychological factors, they are regarded as internal motivators directing individuals' level of policy support. The focus of these factors is about emotional and cognitive state of a person towards a policy. Political factors, by contrast, are external forces driving policy support. They are factors which derive from the political environment where the policy is situated in, and exert influences on people's decision on whether they should show support for a policy. Level of policy support is a joint condition of different factors and it can only be fully understood by investigating its different facets (i.e., socio-demographic characteristics, psychological, and political factors).

\section{Discussion}

Previous section has reviewed literature on potential political factors which have effects on level of policy support. The following section is about some reflections on current issues and some suggestions on future directions for research.

\subsection{Political trust}

Only a few pieces of studies operationalized measurements to distinguishing trust in different political referents (e.g., trust in government as a whole, or politicians, or specific institutions) in studies of environmental policy support. Citrin and Muste (1999) suggested that scholars should specify the object of trust that is being measured. As discussed above, the public's political trust may not be adequately accessed if only a particular government level is being evaluated. Subsequently level of political trust is likely to be magnified or underestimated. It is particular true in countries that the public's civic consciousness is not fully-fledged, implying that respondents are not capable of differentiating political referents and make corresponding evaluations. Therefore, it is suggested that future research should expand current inquiries beyond assessment of political trust in government in an aggregated level, and tries to explore how the level of political trust varies in different political referents and its impact on policy support.

\subsection{Procedural \& distributive fairness}

Current literature have yet fully discussed elements of fair procedures, for example, Kim et al. (2013) and Ebreo et al. (1996) only considered procedural fairness as a blanket of ideas, and grasped respondents' level of perception of fairness by asking question like "Do you think the process of government decision making that lead to an environmental tax is fair?" Evaluation on other aspects of procedural fairness such as whether citizens' voice is being heard or whether they are well represented during decision-making process is rarely discussed in past studies. Future research may examine procedural fairness and its impact on policy support by using different criteria, for instance, compliance with rule of law, respectful treatment to individuals, sufficient representation of citizens, and effective channel for citizens to raise their voices instead of a single aspect or general impression of procedural fairness. Another concerned issue is some scholars argued that perceived justice of environmental policy is based on fairness of decision-making process more than the outcomes (Clayton, 1998), as a consequence, any result found will lost significance (Kals \& Russell, 2001). However, examining outcomes (i.e., distributive fairness) and its influence on policy support is still worthy. As study conducted by Ohnuma et al. (2005) showed, distributive fairness is the core determinant of preferences for strict environmental rules. The result provides a referential point for future research on investigating support for loose-strict environmental policies. 


\subsection{Political affiliation}

Prior research mainly focused on relationships between individuals' political orientation and degree of support for urban environmental policy (Dunlap et al., 2001; Tobler et al., 2012). Studies on relationships between public support and different types of policy instruments of a given environmental policy are rarely found. It should be noted that there can be a wide range of policy tools for addressing a particular kind of environmental problem, for example, voluntary-based programmes like campaigns for promoting pro-environmental behaviours, financial charge/levy such introducing environmental tax or waste charging schemes, statutory instruments such as regulatory framework of air pollutant emission (Elmore, 1987; Wan et al., 2015). As discussed above, conservative-attached individuals generally opposite intervention from the government (e.g., regulations) whilst liberals are more pro-environment and incline to environmental policy in general. In other words, people on different political spectrum may show varying degrees of support on an environmental policy, depending on the nature of the policy instrument, that is, voluntary-based campaigns to financial means to regulatory frameworks. Examining how level of support for different policy tools vary across individuals' political orientation would help the government to formulate policies which can maximize support, and in return, effectively implement the policies and achieve policy goals.

\subsection{Participatory process}

Though research on participatory process and its effects on policy support are welldocumented, most works are based on a single case study and are normative arguments deducted by reasoning. These studies have provided fruitful sources for understanding participatory process and fertile soil for future research. However, the role of participatory process in environment policy and its relation with policy support are yet thoroughly studied. For example, current research relies heavily on single case study (Daley, 2013), which case comparison is rarely found. It should be noticed that single case study does not allow investigation on if level of policy support varies across policies in the absence of participatory processes. By conducting comparative study, research in the field would be benefited from filling with findings on the magnitude to which participatory process affects the degree of citizens' endorsement of environmental policy. In order to increase the reliability, future research should also control other variables which may have effects on policy support. Besides, it is observed that many current studies focus mainly on normative arguments which quantitative testing is hardly found. Hence, it is suggested that scholars may shift their attention to case comparison and more quantitative methods in future research.

\subsection{Policy preference}

Public opinion polls have revealed that people express a strong environmental attitude and tend to support for more government spending on urban environmental policy (Dunlap, 2002; Guber, 2003). However, it is too early jumping into a conclusion that the public are in favour of environmental policy by only looking into the results of these surveys. The multidimension policy preference of environmental policy may disrupt the conclusion of environmental preference of the public. First and foremost, the measurements of environmental policy preference such as by simply asking respondents whether support for environmental protection or willingness to pay more tax for environmental programme do not allow scholars gather accurate preference on environmental policy from the public. This is because there are different types of environmental problems. Respondents may have different 
concerns in different environmental issues. Showing preferences for one particular type of environmental issue does not imply equal endorsement of the others (Daniels et al., 2013).

Moreover, instead of expressing positive preference on a simple attitudinal measurement (e.g., “Are you willing to pay for environmental protection?"), public's policy preferences may originate from their consideration on the extent of willingness to make sacrifice for environmental protection. The degree of preference may diminish in line with the escalation of cost for protecting the environment, so as the level of policy support. Going forward, depending on what types of resources that people have to sacrifice, policy preference may turn out to be different. Some people may prefer using financial means (e.g., paying more taxes, approval of earmarking more government spending) or other types of public resources (e.g., land resources for environmental facilities) for environmental protection while others may favour contributing personal efforts such as spending more time to do recycling in response to government's urban environmental policy. People's preferences and associated policy support may therefore vary with regard to different policy instruments. In order to accurately grasp relationships between people's preferences on environmental issues and corresponding level of support for environmental policy, future research may work on measurements of people's preferences by referring to above arguments.

\section{Conclusions}

This paper has systematically reviewed 88 selected papers retrieved from Scopus and other databases and filled the knowledge gap of policy support by identifying political factors for possible explanation. Five political factors, i.e., political trust, procedural and distributive fairness, political affiliation, participatory policy process, and policy preference, form a new conceptual model which take most political contexts into consideration, ranging from perceptions over a political authority to policy formations. Apart from socio-demographic and psychological factors, future studies can integrate identified political factors into the research framework for policy support investigation. The model also facilitates future discussions and research on policy support of urban environmental policies. Moreover, evaluations of current measurement issues and possible research direction are highlighted in this paper. 


\section{References}

Beierle, T. C., \& Konisky, D. M. (2000). Values, conflict, and trust in participatory environmental planning. Journal of Policy Analysis and Management, 19(4), 587-602.

Beierle, T. C., \& Konisky, D. M. (2001). What are we gaining from stakeholder involvement? Observations from environmental planning in the Great Lakes. Environment and Planning C: Government and Policy, 19(4), 515-527.

Bilotta, G. S., Milner, A. M., \& Boyd, I. (2014). On the use of systematic reviews to inform environmental policies. Environmental Science \& Policy, 42, 67-77.

Blaine, T. W., \& Smith, T. (2006). From water quality to riparian corridors: Assessing willingness to pay for conservation easements using the contingent valuation method. Journal of Extension, 44(2), 115-135.

Blocker, T. J., \& Eckberg, D. L. (1997). Gender and environmentalism: Results from the 1993 General Social Survey. Social Science Quarterly, 78(4), 841-858.

Bloomfield, D., Collins, K., Fry, C., \& Munton, R. (2001). Deliberation and inclusion: vehicles for increasing trust in UK public governance? Environment and Planning C: Government and Policy, 19(4), 501-513.

Börjesson, M., Eliasson, J., \& Hamilton, C. (2016). Why experience changes attitudes to congestion pricing: The case of Gothenburg. Transportation Research Part A: Policy and Practice, 85, 1-16.

Börjesson, M., Eliasson, J., Hugosson, M. B., \& Brundell-Freij, K. (2012). The Stockholm congestion charges-5 years on. Effects, acceptability and lessons learnt. Transport Policy, 20, 1-12.

Börjesson, M., Hamilton, C. J., Näsman, P., \& Papaix, C. (2015). Factors driving public support for road congestion reduction policies: Congestion charging, free public transport and more roads in Stockholm, Helsinki and Lyon. Transportation Research Part A: Policy and Practice, 78, 452-462.

Carman, C. J. (1998). Dimensions of environmental policy support in the United States. Social Science Quarterly, 79(4), 717-733.

Chess, C., \& Purcell, K. (1999). Public participation and the environment: Do we know what works? Environmental Science \& Technology, 33(16), 2685-2692.

Chung, J. Y., Kyle, G. T., Petrick, J. F., \& Absher, J. D. (2011). Fairness of prices, user fee policy and willingness to pay among visitors to a national forest. Tourism Management, 32(5), 1038-1046.

Citrin, J., \& Muste, C. (1999). Trust in government. In J. P. Robinson, P. R. Shaver, \& L. S. Wrightsman (Eds.), Measures of Political Attitudes (pp. 465-532). California, USA; London, UK: Academic Press.

Clayton, S. (1998). Preference for macrojustice versus microjustice in environmental decisions. Environment and Behavior, 30(2), 162-183.

Clayton, S. (2000). New ways of thinking about environmentalism: Models of justice in the environmental debate. Journal of Social Issues, 56(3), 459-474.

Clements, B. (2012). Exploring Public Opinion on the Issue of Climate Change in Britain. British Politics, 7(2), 183-202.

Convery, F., McDonnell, S., \& Ferreira, S. (2007). The most popular tax in Europe? Lessons from the Irish plastic bags levy. Environmental and Resource Economics, 38(1), 1-11.

Cuppen, M., Broekhans, B., \& Enserink, B. (2012). Public participation in EIA and attitude formation. Impact Assessment and Project Appraisal, 30(2), 63-74.

Daley, D. M. (2013). Public Participation, Citizen Engagement, and Environmental Decision Making. In S. Kamieniecki \& M. E. Kraft (Eds.), The Oxford Handbook of U.S. Environmental Policy (pp. 487-503). Oxford; New York: Oxford University Press. 
Daniels, D. P., Krosnick, J. A., Tichy, M. P., \& Tompson, T. (2013). Public Opinion on Environmental Policy in the United States. In S. Kamieniecki \& M. E. Kraft (Eds.), The Oxford Handbook of U.S. Environmental Policy (pp. 461-486). Oxford; New York: Oxford University Press.

Davis, C., \& Fisk, J. M. (2014). Energy Abundance or Environmental Worries? Analyzing Public Support for Fracking in the United States. Review of Policy Research, 31(1), 1-16.

Dietz, T., Dan, A., \& Shwom, R. (2007). Support for climate change policy: Social Psychological and social structural influences. Rural Sociology, 72(2), 185-214.

Dietz, T., Stern, P. C., \& Guagnano, G. A. (1998). Social structural and social psychological bases of environmental concern. Environment and Behavior, 30(4), 450-471.

Dunlap, R. E. (2002). An Enduring Concern. Public Perspective, 13(5), 10-14.

Dunlap, R. E., Van Liere, K. D., Mertig, A. G., \& Jones, R. E. (2000). New trends in measuring environmental attitudes: measuring endorsement of the new ecological paradigm: a revised NEP scale. Journal of Social Issues, 56(3), 425-442.

Dunlap, R. E., Xiao, C., \& McCright, A. M. (2001). Politics and Environment in America: Partisan and Ideological Cleavages in Public Support for Environmentalism. Environmental Politics, 10(4), 23-48.

Dupont, D. P., \& Bateman, I. J. (2012). Political affiliation and willingness to pay: An examination of the nature of benefits and means of provision. Ecological Economics, 75, 43-51.

Easton, D. (1975). A Re-Assessment of the Concept of Political Support. British Journal of Political Science, 5(4), 435-457.

Ebreo, A., Linn, N., \& Vining, J. (1996). The Impact of Procedural Justice on Opinions of Public Policy: Solid Waste Management as an Example. Journal of Applied Social Psychology, 26(14), 1259-1285.

Elliott, E., Regens, J. L., \& Seldon, B. J. (1995). Exploring Variation in Public Support for Environmental Protection. Social Science Quarterly, 76(1), 41-52.

Elliott, E., Seldon, B. J., \& Regens, J. L. (1997). Political and Economic Determinants of Individuals Support for Environmental Spending. Journal of Environmental Management, 51(1), 15-27.

Elmore, R. F. (1987). Instruments and strategy in public policy. Review of Policy Research, 7(1), 174-186.

Folger, R. (1996). Distributive and procedural justice: Multifaceted meanings and interrelations. Social Justice Research, 9(4), 395-416.

Franzen, A. (2003). Environmental attitudes in international comparison: An analysis of the ISSP surveys 1993 and 2000. Social Science Quarterly, 84(2), 297-308.

Gariepy, M. (1991). Toward a dual-influence system: Assessing the effects of public participation in environmental impact assessment for hydro-Quebec projects.

Environmental Impact Assessment Review, 11(4), 353-374.

Garnett, K., \& Cooper, T. (2014). Effective dialogue: enhanced public engagement as a legitimising tool for municipal waste management decision-making. Waste Management, 34(12), 2709-2726.

Gifford, R. (2014). Environmental Psychology Matters. Annual Review of Psychology, 65, 541-579.

Grønhøj, A., \& Thøgersen, J. (2009). Like father, like son? Intergenerational transmission of values, attitudes, and behaviours in the environmental domain. Journal of Environmental Psychology, 29(4), 414-421.

Guber, D. L. (2003). The Grassroots of a Green Revolution: Polling America on the Environment. Cambridge, Mass., United States: MIT Press. 
Haller, M., \& Hadler, M. (2008). Dispositions to act in favor of the environment: Fatalism and readiness to make sacrifices in a cross-national perspective. Sociological Forum, 23(2), 281-311.

Halvorsen, K. E. (2003). Assessing the Effects of Public Participation. Public Administration Review, 63(5), 535-543.

Hardoy, J. E., Mitlin, D., \& Satterthwaite, D. (2013). Environmental Problems in an Urbanizing World: Finding Solutions in Cities in Africa, Asia and Latin America. London, United Kingdom: Taylor \& Francis.

Harring, N. (2013). Understanding the Effects of Corruption and Political Trust on Willingness to Make Economic Sacrifices for Environmental Protection in a CrossNational Perspective. Social Science Quarterly, 94(3), 660-671.

Harring, N., \& Jagers, S. (2013). Should We Trust in Values? Explaining Public Support for Pro-Environmental Taxes. Sustainability, 5(1), 210-227.

Hartley, N., \& Wood, C. (2005). Public participation in environmental impact assessment Implementing the Aarhus Convention. Environmental Impact Assessment Review, 25(4), 319-340.

Hartley, T. W. (2006). Public perception and participation in water reuse. Desalination, 187(1-3), 115-126.

Havel, V. (1996). The World Bank Participation Sourcebook. Washington, United States: World Bank Publications.

Hetherington, M. J. (2006). Why Trust Matters: Declining Political Trust and the Demise of American Liberalism. Princeton, NJ: Princeton University Press.

Hunter, L. M., Hatch, A., \& Johnson, A. (2004). Cross-National Gender Variation in Environmental Behaviors. Social Science Quarterly, 85(3), 677-694.

Inglehart, R. (1995). Public support for environmental protection: Objective problems and subjective values in 43 societies. PS: Political Science \& Politics, 28(1), 57-72.

Innes, J. E., \& Booher, D. E. (2004). Reframing public participation: strategies for the $21 \mathrm{st}$ century. Planning Theory \& Practice, 5(4), 419-436.

Israel, D., \& Levinson, A. (2004). Willingness to Pay for Environmental Quality: Testable Empirical Implications of the Growth and Environment Literature. The B.E. Journal of Economic Analysis \& Policy, 3(1), 1-31.

Jenkins-Smith, H., \& Kunreuther, H. (2001). Mitigation and benefits measures as policy tools for siting potentially hazardous facilities: Determinants of effectiveness and appropriateness. Risk Analysis, 21(2), 371-382.

Johnson, R. J., \& Scicchitano, M. J. (2000). Uncertainty, risk, trust, and information: Public perceptions of environmental issues and willingness to take action. Policy Studies Journal, 28(3), 633-647.

Johnson, T. (2010). Environmentalism and NIMBYism in China: promoting a rules-based approach to public participation. Environmental Politics, 19(3), 430-448.

Jones, R. E., \& Dunlap, R. E. (1992). The social bases of environmental concern: Have they changed over time? Rural Sociology, 57(1), 28-47.

Junker, B., Buchecker, M., \& Müller-Böker, U. (2007). Objectives of public participation: Which actors should be involved in the decision making for river restorations? Water Resources Research, 43(10), 1-11.

Kallbekken, S., \& Sælen, H. (2011). Public acceptance for environmental taxes: Self-interest, environmental and distributional concerns. Energy Policy, 39(5), 2966-2973.

Kals, E., \& Russell, Y. (2001). Individual conceptions of justice and their potential for explaining proenvironmental decision making. Social Justice Research, 14(4), 367-385.

Kamieniecki, S., \& Kraft, M. E. (Eds.). (2013). The Oxford handbook of U.S. environmental policy. Oxford; New York: Oxford University Press. 
Kapoor, I. (2001). Towards participatory environmental management? Journal of Environmental Management, 63(3), 269-279.

Kim, J., Schmöcker, J.-D., Fujii, S., \& Noland, R. B. (2013). Attitudes towards road pricing and environmental taxation among US and UK students. Transportation Research Part A: Policy and Practice, 48, 50-62.

Kingdon, J. W. (1995). Agendas, Alternatives, and Public Policies. New York: Longman.

Kollmann, A., \& Reichl, J. (2015). How Trust in Governments Influences the Acceptance of Environmental Taxes. In F. Schneider, A. Kollmann, \& J. Reichl (Eds.), Political Economy and Instruments of Environmental Politics (pp. 53-70). Cambridge, Mass., United States: MIT Press.

Kollmuss, A., \& Agyeman, J. (2002). Mind the gap: why do people act environmentally and what are the barriers to pro-environmental behavior? Environmental Education Research, $8(3), 239-260$.

Konisky, D. M., Milyo, J., \& Richardson, L. E. (2008). Environmental Policy Attitudes: Issues, Geographical Scale, and Political Trust. Social Science Quarterly, 89(5), 10661085.

Kyselá, E. (2015). Acceptability of environmental policies in the Czech Republic: A comparison with willingness to make economic sacrifices. Social Studies, 12(3), 179-198.

Leiserowitz, A. A., Kates, R. W., \& Parris, T. M. (2006). Sustainability Values, Attitudes, and Behaviors: A Review of Multinational and Global Trends. Annual Review of Environment and Resources, 31(1), 413-444.

León, C. J., \& Araña, J. E. (2016a). Context-dependent evaluation of climate change policies: competing policies, knowledge and emotions. Journal of Environmental Planning and Management, 59(4), 687-707.

León, C. J., \& Araña, J. E. (2016b). The Economic Valuation of Climate Change Policies in Tourism Impact of Joint Valuation, Emotions, and Information. Journal of Travel Research, 55(3), 283-298.

Lester, J. P. (1995). Environmental politics and policy: Theories and evidence. Durham: Duke University Press.

Levi, M., \& Sacks, A. (2009). Legitimating beliefs: Sources and indicators. Regulation \& Governance, 3(4), 311-333.

Levi, M., \& Stoker, L. (2000). Political trust and trustworthiness. Annual Review of Political Science, 3(1), 475-507.

Lima, M. L. (2006). Predictors of Attitudes Towards the Construction of a Waste Incinerator: Two Case Studies1. Journal of Applied Social Psychology, 36(2), 441-466.

Lind, E. A., \& Tyler, T. R. (1988). The social psychology of procedural justice. New York, NY, United State: Springer Science \& Business Media.

Liu, X., Vedlitz, A., \& Shi, L. (2014). Examining the determinants of public environmental concern: Evidence from national public surveys. Environmental Science \& Policy, 39, 77-94.

López-Mosquera, N., Lera-López, F., \& Sánchez, M. (2015). Key factors to explain recycling, car use and environmentally responsible purchase behaviors: A comparative perspective. Resources, Conservation and Recycling, 99, 29-39.

Lubell, M., Vedlitz, A., Zahran, S., \& Alston, L. T. (2006). Collective action, environmental activism, and air quality policy. Political Research Quarterly, 59(1), 149-160.

Luyet, V., Schlaepfer, R., Parlange, M. B., \& Buttler, A. (2012). A framework to implement Stakeholder participation in environmental projects. Journal of Environmental Management, 111, 213-219.

MacCoun, R. J. (2005). Voice, control, and belonging: The double-edged sword of procedural fairness. Annual Review of Law and Social Science, 1, 171-201. 
Major, A. M., \& Atwood, L. E. (2004). Environmental risks in the news: issues, sources, problems, and values. Public Understanding of Science, 13(3), 295-308.

Mankad, A., Walton, A., \& Alexander, K. (2015). Key dimensions of public acceptance for managed aquifer recharge of urban stormwater. Journal of Cleaner Production, 89, 214223.

Matti, S. (2010). Sticks Carrots and Legitimate Policies - Effectiveness and Acceptance in Environmental Public Policy. In P. Söderholm (Ed.), Environmental policy and household behaviour : sustainability and everyday life. London, United Kingdom: Taylor \& Francis Ltd.

Matti, S. (2015). Climate policy instruments. In K. Backstrand \& E. Lovbrand (Eds.), Research Handbook on Climate Governance. Cheltenham, United Kingdom: Edward Elgar Publishing Ltd.

McCright, A. M., \& Dunlap, R. E. (2013). Bringing ideology in: the conservative white male effect on worry about environmental problems in the USA. Journal of Risk Research, 16(2), 211-226.

McCright, A. M., Dunlap, R. E., \& Xiao, C. (2014). Increasing influence of party identification on perceived scientific agreement and support for government action on climate change in the United States, 2006-12. Weather, Climate, and Society, 6(2), 194201.

McCright, A. M., Xiao, C., \& Dunlap, R. E. (2014). Political polarization on support for government spending on environmental protection in the USA, 1974-2012. Social Science Research, 48, 251-260.

Miller, A. H. (1974). Political issues and trust in government: 1964-1970. American Political Science Review, 68(3), 951-972.

Milon, J. W., \& Scrogin, D. (2006). Latent preferences and valuation of wetland ecosystem restoration. Ecological Economics, 56(2), 162-175.

Mostafa, M. M. (2012). Does globalisation affect consumers' pro-environmental intentions? A multilevel analysis across 25 countries. International Journal of Sustainable Development \& World Ecology, 19(3), 229-237.

Neumayer, E. (2004). The environment, left-wing political orientation and ecological economics. Ecological Economics, 51(3), 167-175.

North, D. C. (1990). Institutions, Institutional Change and Economic Performance. Cambridge, United Kingdom: Cambridge University Press.

OECD. (2009). OECD Studies on Public Engagement Focus on Citizens: Public Engagement for Better Policy and Services. Paris, France: OECD.

Ohnuma, S., Hirose, Y., Karasawa, K., Yorifuji, K., \& Sugiura, J. (2005). Why do residents accept a demanding rule?: Fairness and social benefit as determinants of approval of a recycling system. Japanese Psychological Research, 47(1), 1-11.

Ormerod, K. J., \& Scott, C. A. (2013). Drinking Wastewater: Public Trust in Potable Reuse. Science Technology and Human Values, 38(3), 351-373.

Page, B., \& Shapiro, R. Y. (1993). The Rational Public and Democracy. In G. E. Marcus \& R. L. Hanson (Eds.), Reconsidering the Democratic Public (pp. 35-64). Pennsylvania, United States: Pennsylvania State University Press.

Page, B. I., \& Shapiro, R. Y. (2010). The Rational Public: Fifty Years of Trends in Americans' Policy Preferences. United States: University of Chicago Press.

Petts, J. (2000). Municipal waste management: inequities and the role of deliberation. Risk Analysis, 20(6), 821-832.

Petts, J. (2001). Evaluating the effectiveness of deliberative processes: waste management case-studies. Journal of Environmental Planning and Management, 44(2), 207-226. 
Podhora, E. (2015). Lessons for climate change reform from environmental history: 19Th Century wildlife protection and the 20th Century environmental. Journal of Environmental Law and Litigation, 30(1), 1-55.

Rahardyan, B., Matsuto, T., Kakuta, Y., \& Tanaka, N. (2004). Resident's concerns and attitudes towards Solid Waste Management facilities. Waste Management, 24(5), 437451.

Rasinski, K. A., Smith, T. W., \& Zuckerbraun, S. (1994). Fairness motivations and tradeoffs underlying public support for government environmental spending in nine nations. Journal of Social Issues, 50(3), 179-197.

Rauwald, K. S., \& Moore, C. F. (2002). Environmental attitudes as predictors of policy support across three countries. Environment and Behavior, 34(6), 709-739.

Reed, M. S. (2008). Stakeholder participation for environmental management: A literature review. Biological Conservation, 141(10), 2417-2431.

Reese, G., \& Jacob, L. (2015). Principles of environmental justice and pro-environmental action: A two-step process model of moral anger and responsibility to act. Environmental Science \& Policy, 51, 88-94.

Renn, O. (2006). Participatory processes for designing environmental policies. Land Use Policy, 23(1), 34-43.

Rietig, K. (2016). The power of strategy: Environmental NGO influence in international climate negotiations. Global Governance, 22(2), 269-288.

Roberts, N. (2004). Public Deliberation in an Age of Direct Citizen Participation. The American Review of Public Administration, 34(4), 315-353.

Roomratanapun, W. (2001). Introducing centralised wastewater treatment in Bangkok: A study of factors determining its acceptability. Habitat International, 25(3), 359-371.

Satterthwaite, D. (2003). The links between poverty and the environment in urban areas of Africa, Asia, and Latin America. The Annals of the American Academy of Political and Social Science, 590(1), 73-92.

Schuitema, G., \& Bergstad, C. J. (2012). Acceptability of environmental policies. In L. Steg, A. E. van den Berg, \& J. I. M. de Groot (Eds.), Environmental Psychology: An Introduction (pp. 255-266). Hoboken, United States: John Wiley and Sons Ltd.

Shepherd, A., \& Bowler, C. (1997). Beyond the requirements: Improving public participation in EIA. Journal of Environmental Planning and Management, 40(6), 725-738.

Steg, L., Dreijerink, L., \& Abrahamse, W. (2005). Factors influencing the acceptability of energy policies: A test of VBN theory. Journal of Environmental Psychology, 25(4), 415-425.

Steg, L., \& Gifford, R. (2008). Social psychology and environmental problems. In L. Steg, A. P. Buunk, \& T. Rothengatter (Eds.), Applied Social Psychological: Understanding and Managing Social Problems. Cambridge, United Kingdom: Cambridge University Press.

Steg, L., van den Berg, A. E., \& de Groot, J. I. M. (2012). Environmental Psychology: An Introduction. Hoboken, United States: John Wiley and Sons.

Steg, L., \& Vlek, C. (2009). Encouraging pro-environmental behavior: An integrative review and research agenda. Journal of Environmental Psychology, 29, 209-317.

Stern, P. C. (2000). New Environmental Theories: Toward a Coherent Theory of Environmentally Significant Behavior. Journal of Social Issues, 56(3), 407-424.

Stern, P. C., Dietz, T., Abel, T. D., Guagnano, G. A., \& Kalof, L. (1999). A Value-BeliefNorm Theory of Support for Social Movements: The Case of Environmentalism. Human Ecology Review, 6(2), 81-97.

Stern, P. C., Dietz, T., \& Kalof, L. (1993). Value orientations, gender, and environmental concern. Environment and Behavior, 25(5), 322-348. 
Stoutenborough, J. W., Bromley-Trujillo, R., \& Vedlitz, A. (2014). Public support for climate change policy: Consistency in the influence of values and attitudes over time and across specific policy alternatives. Review of Policy Research, 31(6), 555-583.

Syme, G. J., Nancarrow, B. E., \& McCreddin, J. A. (1999). Defining the components of fairness in the allocation of water to environmental and human uses. Journal of Environmental Management, 57(1), 51-70.

The World Bank. (1993). The demand for water in rural areas: Determinants and policy implications. World Bank Research Observer, 8(1), 47-70.

Tobler, C., Visschers, V. H. M., \& Siegrist, M. (2012). Addressing climate change: Determinants of consumers' willingness to act and to support policy measures. Journal of Environmental Psychology, 32(3), 197-207.

Torgler, B., \& García-Valiñas, M. A. (2007). The determinants of individuals' attitudes towards preventing environmental damage. Ecological Economics, 63(2-3), 536-552.

Tranfield, D., Denyer, D., \& Smart, P. (2003). Towards a metholology for developing evidence-informed management knowledge by means of systematic review. British Journal of Management, 14, 207-222.

Tyler, T. R., \& Bies, R. J. (1990). Beyond Formal Procedures: The Interpersonal Context of Procedural Justice. In J. Carroll (Ed.), Applied Social Psychology and Organizational Settings (pp. 77-98). Hillsdale, NJ: L. Erlbaum Associates.

Uyeki, E. S., \& Holland, L. J. (2000). Diffusion of pro-environment attitudes? American Behavioral Scientist, 43(4), 646-662.

Van Kamp, I., Leidelmeijer, K., Marsman, G., \& De Hollander, A. (2003). Urban environmental quality and human well-being: Towards a conceptual framework and demarcation of concepts; a literature study. Landscape and Urban Planning, 65(1), 5-18.

Wallner, J. (2008). Legitimacy and Public Policy: Seeing Beyond Effectiveness, Efficiency, and Performance. Policy Studies Journal, 36(3), 421-443.

Wan, C., Shen, G. Q., \& Yu, A. (2015). Key determinants of willingness to support policy measures on recycling: A case study in Hong Kong. Environmental Science \& Policy, 54, 409-418.

Warren, M. (1999). Democracy and Trust. Cambridge: Cambridge University Press.

Webler, T., Kastenholz, H., \& Renn, O. (1995). Public participation in impact assessment: A social learning perspective. Environmental Impact Assessment Review, 15(5), 443-463.

Webler, T., Tuler, S., \& Krueger, R. (2001). What Is a Good Public Participation Process? Five Perspectives from the Public. Environmental Management, 27(3), 435-450.

Wlezien, C. (1995). The public as Thermostat: Dynamics of Preferences for Spending. American Journal of Political Science, 39(4), 981-1000.

$\mathrm{Xu}, \mathrm{J} .$, \& Li, J. (2016). Tax payment, social contribution for pollution prevention and happiness. Problemy Ekorozwoju, 11(1), 59-64.

Zannakis, M., Wallin, A., \& Johansson, L.-O. (2015). Political Trust and Perceptions of the Quality of Institutional Arrangements - how do they influence the public's acceptance of environmental rules. Environmental Policy and Governance, 25(6), 424-438.

Zelezny, L. C., Chua, P. P., \& Aldrich, C. (2000). New ways of thinking about environmentalism: Elaborating on gender differences in environmentalism. Journal of Social Issues, 56(3), 443-457. 
Appendix 1 - List of Reviewed Articles

\begin{tabular}{|c|c|c|}
\hline Political Database & Scopus & $\begin{array}{c}\text { Databases other than Scopus } \\
\text { (EBSCOhost Academic Search Premier, JSTOR, } \\
\text { ProQuest, SpringerLink, and Wiley Online } \\
\text { Library) }\end{array}$ \\
\hline Political Trust & $\begin{array}{l}\text { Xu \& Li (2016) } \\
\text { Lubell et al. (2006) } \\
\text { Jenkins-Smith \& Kunreuther (2001) } \\
\text { Hartley (2006) } \\
\text { Ormerod \& Scott (2013) } \\
\text { Konisky et al. (2008) } \\
\text { Kyselá (2015) } \\
\text { Harring (2013) }\end{array}$ & $\begin{array}{l}\text { Harring \& Jagers (2013) } \\
\text { Kollmann \& Reichl (2015) } \\
\text { Zannakis et al. (2015) } \\
\text { Johnson \& Scicchitano (2000) }\end{array}$ \\
\hline $\begin{array}{l}\text { Procedural \& } \\
\text { Distributive Fairness }\end{array}$ & $\begin{array}{l}\text { Börjesson et al. (2012; 2015; 2016) } \\
\text { Mankad et al. }(2015) \\
\text { Syme et al. (1999) } \\
\text { Folger (1996) } \\
\text { Chung et al. (2011) }\end{array}$ & $\begin{array}{l}\text { Kals \& Russell (2001) } \\
\text { Ohnuma et al. (2005) } \\
\text { Rahardyan et al. (2004) } \\
\text { Lima (2006) } \\
\text { Kim et al. (2013) } \\
\text { Rasinski et al. (1994) } \\
\text { Clayton (1998; 2000) } \\
\text { Reese \& Jacob (2015) } \\
\text { Ebreo et al. (1996) } \\
\text { MacCoun (2005) }\end{array}$ \\
\hline Political Affiliation & $\begin{array}{l}\text { Stoutenborough et al. (2014) } \\
\text { Dietz et al. (2007) } \\
\text { Clements (2012) } \\
\text { Tobler et al. (2012) } \\
\text { Carman (1998) } \\
\text { Davis \& Fisk (2014) } \\
\text { Haller \& Hadler (2008) }\end{array}$ & $\begin{array}{l}\text { McCright et al. (2014a; 2014b) } \\
\text { Konisky et al. (2008) } \\
\text { Dupont \& Bateman (2012) } \\
\text { Elliott et al. (1997) } \\
\text { Dunlap et al. (2001) } \\
\text { Uyeki \& Holland (2000) } \\
\text { Liu et al. (2014) } \\
\text { Neumayer (2004) } \\
\text { Torgler \& García-Valiñas (2007) }\end{array}$ \\
\hline Participatory Process & $\begin{array}{l}\text { Rietig (2016) } \\
\text { Roomratanapun (2001) } \\
\text { Roberts (2004) } \\
\text { Halvorsen (2003) } \\
\text { Shepherd \& Bowler (1997) } \\
\text { Hartley \& Wood (2005) } \\
\text { Cuppen et al. (2012) } \\
\text { Webler et al. (1995) } \\
\text { Gariepy (1991) }\end{array}$ & $\begin{array}{l}\text { Garnett \& Cooper (2014) } \\
\text { Petts (2000; 2001) } \\
\text { Daley (2013) } \\
\text { Innes \& Booher (2004) } \\
\text { Johnson (2010) } \\
\text { Havel (1996) } \\
\text { Reed (2008) } \\
\text { Renn (2006) } \\
\text { Bloomfield (2001) } \\
\text { Kapoor (2001) } \\
\text { Beierle \& Konisky (2000) } \\
\text { Webler et al. (2001) } \\
\text { Beierle \& Konisky (2001) } \\
\text { Luyet et al. (2012) } \\
\text { Junker et al. (2007) } \\
\text { Chess \& Purcell (1999) }\end{array}$ \\
\hline Policy Preference & $\begin{array}{l}\text { León \& Araña }(2016 \mathrm{a}, 2016 \mathrm{~b}) \\
\text { The World Bank (1993) } \\
\text { Podhora (2015) } \\
\text { Milon and Scrogin (2006) } \\
\text { Blaine and Smith (2006) }\end{array}$ & $\begin{array}{l}\text { Page and Shapiro }(1993 ; 2010) \\
\text { Elliott et al. (1995) } \\
\text { Inglehart (1995) } \\
\text { Leiserowitz et al. (2006) } \\
\text { Daniels et al. (2013) } \\
\text { Dunlap (2002) } \\
\text { Guber (2003) } \\
\text { Wan et al. (2015) }\end{array}$ \\
\hline
\end{tabular}

